\title{
trabalhonecessário
}

issn: $1808-799 X$

ano 7 - número 8 - 2009

\section{O trabalho produtivo do músico nas casas de shows da Lapa: um estudo de caso.}

\author{
Luciana Requião ${ }^{1}$ - lucianarequiao@inpauta.com.br
}

\author{
"A arte é quase tão antiga quanto o homem.É uma \\ forma de trabalho, e o trabalho é uma \\ característica do homem". \\ Ernest Fischer
}

Este texto apresenta parte das reflexões contidas na tese intitulada "Eis aí a Lapa...": processos e relações de trabalho do músico nas casas de shows da Lapa, em que buscamos articular os processos gerais da produção capitalista ao trabalho específico do músico no capitalismo tardio. Tendo como objetivo geral analisar, discutir e compreender os atuais processos e relações de trabalho deste setor produtivo, em específico o trabalho do músico em apresentações ao vivo, procuramos demonstrar que os processos de produção da música não são processos autônomos e que para compreendê-los se faz necessária uma análise do contexto sócio, político, econômico e cultural onde estão inseridos. Por trás de jargões que pregam a democratização do acesso à cultura e o apoio à diversidade cultural observamos, na realidade, um processo de transformação de manifestações culturais em mercadoria, o que torna o trabalho do músico um trabalho produtivo ao capital.

As relações e os processos de trabalho do músico nas casas de shows da Lapa foi o foco central da observação empírica, onde se pôde observar as principais características e contradições das relações de trabalho que vêm se estabelecendo no capitalismo tardio. Foi possível constatar que em todas as suas formas, sendo elas legalizadas ou não, a exploração da força de trabalho do músico se perpetua amparada por um regime econômico que permite ao capitalista adequar tais relações de trabalho da forma que the assegure e amplie a sua margem de lucro - objetivo final de qualquer empreendimento capitalista. Como resultado desse estudo, se pôde evidenciar a produção 


\section{trabalhonecessário}

issn: $1808-799 X$

ano 7 - número 8 - 2009

musical como um setor imerso nos processos gerais da produção capitalista, cujas determinações históricas vão moldando e adequando seus processos e suas relações de trabalho às necessidades capitalistas de produção e geração de lucro.

No Rio de Janeiro, a Lapa, que no início do século $X X$ aglutinava intelectuais, malandros e prostitutas, entre outros personagens ilustres ou anônimos da vida noturna carioca, passou por um período de esvaziamento que durou algumas décadas. Presenciamos na atualidade um movimento que vem sendo reconhecido como a "revitalização da Lapa", com a reforma dos seus casarões e a abertura de inúmeras casas de shows. Hoje, a Lapa vem reunindo um público com alto poder aquisitivo - como turistas de diversas localidades - usando como atrativo a famosa boemia carioca e a música popular. Contando hoje com dezenas de casas de shows, a Lapa apresenta um alto potencial de desenvolvimento econômico atraindo cerca de 10.000 visitantes por semana, gerando uma movimentação financeira em torno de 3,6 milhões de reais semanais ${ }^{2}$.

Se por um lado a efervescência do local ampliou a demanda pela força de trabalho especializada do músico, por outro lado vem ocultando relações de trabalho cada vez mais precarizadas. O fenômeno artístico fetichizado esconde a essência de um trabalho cada vez mais informal e precarizado. É dessa Lapa que iremos tratar.

“Eis aí a Lapa...”: um breve histórico.

"Um samba um Sorriso de mulher bate papo de café eis aí a Lapa".

Wilson Batista e Marino Pinto

A Lapa é uma área localizada no Centro da cidade do Rio de Janeiro, bairro pertencente à Região Centro, e é conhecida por ser um reduto da boemia carioca ${ }^{3}$. A ocupação dessa área de forma mais organizada teve início 


\section{trabalhonecessário}

issn: $1808-799 \mathrm{X}$

ano 7 - número 8 - 2009

no século XVIII, tendo sido freqüentada com maior intensidade desde o final do século XIX por intelectuais, artistas e políticos, além dos malandros e das prostitutas.

A grande circulação de intelectuais, políticos, artistas e de comerciantes na área não foi por acaso. A Região Centro é o ponto de origem da cidade do Rio de Janeiro, congregando não só o comércio como importantes instituições públicas:

Começam de fato aí, no morro do Castelo, todas as funções da Cidade, suas atividades econômicas e sociais e o início do desenvolvimento urbano. No alto do morro do Castelo foram construídas uma igreja consagrada a São Sebastião, o Colégio dos Jesuítas, a Cadeia e a Sede do Governo, com os seus foros, A Casa do Tesouro e as demais repartições da época ${ }^{4}$.

Em seus primórdios, a população que vivia abaixo do morro do Castelo era composta de colonizadores portugueses, mamelucos e índios, ficando a população mais abastada em sua superfície ${ }^{5}$. Apesar de contar com numerosa população de baixa renda, os arredores da Lapa, no final do século XIX, vivenciou uma movimentação intensa de personalidades ilustres:

O Grande Hotel, edificado em 1896, pelo Comendador Guilherme Porto e que hoje abriga a Sala Cecília Meireles, foi um hotel importante e luxuoso, porque era utilizado por figuras importantes da República, graças à sua proximidade com o Senado Federal no Palácio Monroe ${ }^{6}$.

No início do século XX o prefeito Pereira Passos promoveu uma reforma na Região do Centro, que,

Abandonando definitivamente suas características coloniais, onde proliferavam cortiços e edificações degradadas, ruas estreitas e insalubres, para se apresentar como grande metrópole moderna e influenciada pelo urbanismo francês de Haussmann, o grande reformador de Paris ${ }^{7}$.

Assim, monumentos arquitetônicos como o Teatro Nacional e a Biblioteca Nacional são construídos nos arredores e a Lapa ganha o status de a Montmartre carioca.

A Lapa das primeiras décadas do século 20 ostentava ares parisienses, sendo logo identificada com Pigalle, Montmartre ou Montparnasse. Sua língua, ao menos aquela falada pelos intelectuais e pelas mais finas marafonas, era o francês. Luís Martins, no "Noturno", lembra discussões intermináveis acerca da poesia de Laforgue, Baudelarie e Rimbaud travadas nas mesas dos bares "49" (que ficava na Rua da Lapa, "a sala era um corredor úmido e penumbrento, cheirando a maresia e beira de cais", segundo a memória de elefante do jornalista Joel 


\section{trabalhonecessário}

issn: $1808-799 \mathrm{X}$

ano 7 - número 8 - 2009

Silveira) ou "Túnel da Lapa" (na Rua Visconde de Maranguape, que também foi restaurante e casa de música) ${ }^{8}$.

A expansão urbana da reforma Passos acaba por delegar a Região Centro o papel de dividir a cidade em duas áreas distintas: "a Zonal Sul para a classe rica e para a burguesia abastada, e a Zona Norte para a classe operária e a população de baixa renda"'.

Quando se fala na Lapa do Rio de Janeiro, o que frequentemente nos vem à mente é a idéia romântica de uma harmoniosa convivência entre malandros, prostitutas, intelectuais, políticos e artistas, sempre envoltos à fumaça de cigarro, bebida e samba. Em seu livro "Lapa: alegres trópicos" (1998), Moacyr Andrade nos confirma a convivência desses personagens na primeira metade do século XX.

Em noite de farra nos anos 20, Zeca Patrocínio e Manuel Bandeira, na companhia de "duas belezas venais", segundo a caracterização do poeta de Pasárgada, testemunharam, "em certa casa inconfessável da Rua Riachuelo", um fantástico concerto de violão brasileiro. Dócil e realizado, o instrumento passava de mão em mão, de Jaime Ovalle a João Pernambuco, deste a Catulo da Paixão Cearense e, em seguida, a Heitor Villa-Lobos. O endereço escuso - a adotar-se a ótica de Bandeira, talvez o único ali, no máximo ao lado de João Pernambuco, inclinado a moderações - era provavelmente o bordel da Elvira. Ao evocar sua despedida desse castelo rumo à Semana de Arte Moderna de São Paulo, cansado de aventuras amorosas e com a boca amarga do álcool, como contaria muitos anos depois, o pintor Di Cavalcanti chamou-o, em poema por sinal dedicado a Jaime Ovalle, de "antro do maestro Villa-Lobos". Vira muitas vezes o gênio musical no recinto, a improvisar sonatas ao piano, entre imensos espelhos e almofadas de cetim (ANDRADE, 1998, pp.7-8).

A economia do local girava em torno da prostituição, que gerava o movimento dos bordéis, clubes, cabarés e botequins. Muitas das boates, restaurantes e bares ofereciam música ao vivo para seus clientes. Porém, segundo nos conta Andrade (1998), o que se ouvia eram orquestras ciganas, tango argentino, trechos de óperas, valsas alemãs, serenatas de Schubert e Brahms. Apesar de compositores como Noel Rosa e Wilson Batista terem escrito músicas com letras que remetem à Lapa ou contam a trajetória de algum personagem ilustre do local - como "Dama do cabaré"10 de Noel Rosa e "Largo da Lapa"11 de Wilson Batista -, Andrade diz que não havia muita música brasileira por ali: "Sinhô preferiria as gafieiras do Catete, Pixinguinha a Praça Tiradentes, Ismael Silva e Nilton Bastos evidentemente o Estácio e Nelson 


\section{trabalhonecessário}

issn: $1808-799 X$

ano 7 - número 8 - 2009

Cavaquinho e Brancura, o Mangue" (idem, p.39). Além disso, conforme comenta Franceschi (2002),

Forçoso é confessar: se a Lapa deu poema de Manuel Bandeira, romance de Luiz Martins, se sobre ela se escreveram cinco mil crônicas, infelizmente não deu a música que seria justo esperar. Tendo todos os elementos inspiradores dos sambistas e chorões, o bairro das 'quatro letras' só muito mais tarde, já em decadência, provocou meia-dúzia de sambas, músicas que não nasceram lá, que usaram o tema apenas como motivo, sem maior ligação com a realidade (FRANCESCHI, 2002, p.289).

Assim como as letras dos sambas, as crônicas e os romances sobre a Lapa nos dão a impressão de uma convivência sem conflitos entre esses espaços públicos e seus freqüentadores, entre eles malandros e "traficantes de alcalóides" (ANDRADE, 1998, p.39).

Luís Martins, que pertenceu à geração seguinte de freqüentadores e foi o romancista desse Éden, destacava precisamente três desses boêmios de talento: Ovalle, Di Cavalcanti e Bandeira, aos quais juntava, entre outros, os poetas Raul de Leoni e Dante Milano, o escritor e diplomata Ribeiro Couto, o jornalista Oswaldo Costa e o ensaísta Sérgio Buarque de Hollanda, caçula da turma, como integrantes do núcleo que inventou a Lapa, "criou a sua legenda romântica de versão montmartriana dos trópicos" (ANDRADE, 1998, p.10).

Entretanto essa imagem da Lapa não era unânime. Andrade conta que para o contista paulista Almeida Fischer a Lapa não tinha essa poesia toda. Também freqüentador do local, dizia:

"Frequentemente há brigas, há roubos, há mortes nas velhas e lúgubres casas de cômodos, nos bares ou nos cabarés, onde os marinheiros de várias raças e vagabundos boêmios nacionais enchem suas horas vazias". As bailarinas dos cabarés? Tristes e insignificantes, de olhos sem brilho - "e no seu sangue pobre, legiões de treponemas" (ANDRADE, 1998, p.16).

No imaginário das letras dos sambas, porém, perdurou uma imagem de um Rio Antigo que se tem saudade, e a esperança da volta dos "tempos áureos" vividos na Lapa. A letra da canção "Lapa" de Benedito Lacerda e Herivelto Martins expressa bem o que Andrade analisa como "uma aspiração generalizada" à uma idéia romantizada do que seria a Lapa (idem, p.52). A letra comemora: "A Lapa está voltando a ser a Lapa".

Ainda segundo Andrade, o que se viu na virada dos anos 1940 para os anos 1950 foi uma brusca mudança nos hábitos e na movimentação econômica da Lapa. Isso se deve a dois acontecimentos importantes: o Estado Novo e a 


\section{trabalhonecessário}

issn: $1808-799 \mathrm{X}$

ano 7 - número 8 - 2009

Segunda Guerra Mundial. "O regime getulista fechou-lhe os prostíbulos, numa cruzada moralista executada sob o comando de um coronel de artilharia, o chefe de polícia Alcides Gonçalves Etchegoyen. Promoveu uma caçada aos malandros e às prostitutas" (ANDRADE, 1998, p.63). Já a Segunda Guerra "infestou a área de marinheiros louros com os bolsos a explodir de dólares" (idem, p.64). Com a instalação da frota americana nos bares e cabarés vieram as vitrolas automáticas: "a proliferação desses engenhos expulsou as orquestras e pequenos conjuntos que faziam a música ao vivo (...) até nos botequins mais modestos" (idem).

Na década de 1950, com o surto industrial surgido no pós-guerra, a região começa a sofrer um processo de esvaziamento. Na década seguinte, com a mudança da capital federal para Brasília e a transformação da Cidade em Estado da Guanabara, o desenvolvimentismo e a febre viária desfiguram, mais uma vez, o Centro, onde são construídos viadutos e pistas expressas elevadas voltadas para o atendimento ao transporte por automóvel ${ }^{12}$.

Por conta dessa situação "intelectuais, artistas e políticos atravessaram os túneis rumo a Copacabana, as boates tomavam o lugar dos cabarés" (ANDRADE, 1998, p.65). Assim, os "holofotes" da cultura e da boemia carioca foram desviados para a zona sul da cidade onde nascia a bossa-nova.

Nos anos 1980, quando se deu a instalação do Circo Voador ${ }^{13}$ no Largo da Lapa, trazendo consigo o agito em torno do rock nacional, o chamado BRock, a Lapa volta a ser um dos centros de referencia para a vida cultural da cidade $^{14}$. Mas a concentração era prioritariamente nos arredores dos arcos e nos restaurantes que subsistiram às mudanças no local, como o Bar Brasil, o Cosmopolita e o Capela (hoje Nova Capela).

O historiador Milton Teixeira relata o processo que levaria a revitalização da Lapa da seguinte forma:

A Lapa então mergulha numa era de abandono que perdura até 40 anos depois, quando o governo Chagas Freitas começa a por tudo abaixo. [...] $\mathrm{O}$ ponto de virada dessa história é a manifestação popular para evitar o desmonte do prédio da Fundição Progresso, convertida em espaço cultural. Foi a mola mestra do movimento que ressuscitou a região (Revista Carta Capital, 2007, p.14).

Segundo Magalhães (2006), a chamada "revitalização" da Lapa teve como marco os primeiros anos da década de 1990, quando o governo do 


\section{trabalhonecessário}

issn: $1808-799 \mathrm{X}$

ano 7 - número 8 - 2009

estado criou o projeto Quadra da Cultura. Esse projeto destinou alguns dos imóveis de propriedade do estado, antes ocupados pelo comércio, a abrigar instituições como o Teatro do Oprimido, dirigido por Augusto Boal, e a Federação dos blocos Afros e Afoxés do Rio de Janeiro (MAGALHÃES, 2006).

O projeto Quadra da Cultura contribuiu muito para sinalizar a área como um local em vias de recuperação. Estabeleceu-se, então um circuito que incluía espetáculos, bailes e festas no Circo Voador, na Fundição Progresso, nas casas da Quadra da Cultura, e no Asa Branca. Posteriormente, surgiu, também, uma nova área de atividades boêmias composta pelos restaurantes e bares do trecho inicial da Rua Joaquim Silva, da Rua Visconde de Maranguape e do Largo da Lapa, que passaram a ter atividades noturna com música ao vivo (MAGALHÃES, 2006) ${ }^{15}$.

O projeto do Distrito Cultural da Lapa, criado posteriormente, pretendeu ampliar e dar seqüência ao projeto Quadra da Cultura ${ }^{16}$. Segundo Magalhães (idem), a idéia central é o desenvolvimento sócio-econômico da região com a recuperação do patrimônio imobiliário público, treinamento de mão de obra em cursos artísticos e profissionalizantes, implantação de serviços essenciais à comunidade, destinação de espaços para atividades artísticas e culturais, e investimentos no turismo. O projeto "Distrito Cultural da Lapa" foi instituído em 2000 pela prefeitura, através do Decreto Estadual $n^{\circ} 26.459^{17}$, delimitando o território que compreende o "Largo da Lapa até o final da Rua do Lavradio incluindo a Travessa do Mosqueira, Avenida Mem de Sá, Rua do Riachuelo, Avenida Gomes Freire, Rua dos Arcos, Rua Joaquim Silva, Rua do Resende e Rua da Relação, no Município do Rio de Janeiro" ${ }^{18}$.

Paralelamente e conjuntamente aos projetos promovidos pelo governo do estado, empresários e proprietários de bares, restaurantes e dos inúmeros antiquários da região, já começavam a criar, de forma ainda incipiente, um público atraído também pelas rodas de samba e choro que se formavam no local. O produtor Lefê Almeida, identificado pela maioria dos 80 músicos que responderam ao questionário aplicado no decorrer desta pesquisa como o primeiro a investir na música ao vivo nessa nova fase da região, conta que

A Lapa de hoje não nasceu por acaso. Ela já estava lá. Sempre esteve. Só faltava a Música Popular Carioca para acender o grande palco. O renascimento da Lapa é resultado da persistência, da crença na nossa música popular, das andanças pelo mundo do samba, pela vida boêmia do Rio de Janeiro ${ }^{19}$. 


\section{trabalhonecessário}

issn: $1808-799 X$

ano 7 - número 8 - 2009

O músico Henrique Cazes, ex-diretor musical da casa Rio Scenarium

situada na Rua do Lavradio, indica que no início da década de 1990 ainda eram poucas as casas que ofereciam música ao vivo e que seu aparato técnico era bastante precário. Segundo ele, a contratação de músicos era totalmente informal. Apesar das condições oferecidas aos músicos e aos consumidores, um público interessado em ouvir samba e choro começava na década de 1990, paulatinamente, a freqüentar as casas e sinalizar o potencial econômico que a receita "samba+choro+serviço de bar e restaurante" poderia ter.

A reforma de casarões, provavelmente amparada pelas leis de incentivo à reforma arquitetônica da Lapa, e sua transformação em bares e restaurantes com a oferta de música ao vivo, fez com que o mercado musical se movimentasse criando um nicho de mercado, que pode se dizer "lapiano".

Cazes conta que o bar Empório 100, instalado inicialmente na Rua do Lavradio 100 , foi o primeiro a apresentar tais características, e a casa de shows Carioca da Gema, situada na Avenida Mem de Sá, é identificada como um dos marcos desse processo de revitalização da Lapa.

O cara que fez o negócio do Empório 100 [Lefê Almeida] foi o mesmo que fez o Carioca da Gema. Tudo nasceu muito informalmente. Na época todos acharam que seria uma coisa muito fraca do ponto de vista de oportunidade profissional. Mas o que aconteceu é que a coisa começou a encher e começou a se ganhar nesses lugares o que não se ganhava fazendo show em lugar nenhum ${ }^{20}$.

Em depoimento ao jornal O Globo o próprio Lefê Almeida conta como se deu esse processo:

As portas da Lapa se abriram para mim em meados de 1996, quando fui convidado para fazer shows no Arco da Velha, que reabriu em outubro de 1996 com uma grande roda de samba e a apresentação de vários artistas e compositores. Eu ficava com a programação de quinta e sexta-feira (...). Saímos do Arco da Velha em janeiro de 97 para fazer o Bar Coisa da Antiga, que batizei com esse nome em homenagem ao samba de Wilson Moreira e Nei Lopes. Funcionava num antiquário na rua do Lavradio 100 e ficou mais conhecido pelo seu endereço do que pelo próprio nome. Em meados de 97, Teresa Cristina e o grupo Semente começaram a fazer grande sucesso no bar que dá nome ao conjunto. Ali passou a ser outro grande reduto do samba na Lapa. Em junho de 2000 veio o Carioca da Gema, com uma estrutura de palco e som melhores do que as que eu tinha encontrado antes. Pude fazer uma produção musicalmente mais requintada ${ }^{21}$. 


\section{trabalhonecessário}

issn: $1808-799 X$

ano 7 - número 8 - 2009

O crescimento do número de casas de shows e o fortalecimento da

marca "Lapa" como sinônimo de música brasileira (em especial o samba) significou para o músico a ampliação da demanda por esta força de trabalho especializada. Apesar de a Lapa ser uma localidade, já se fala na Lapa como uma marca quando a mídia anuncia como atração do bairro Barra da Tijuca, zona oeste da cidade: "os arcos da Lapa chegaram a Barra". Outro indício dessa "mercadorificação" da marca Lapa são produtos como o CD Da Lapa lançado pela gravadora Biscoito $\mathrm{Fino}^{22}$, uma "compilação de gravações registradas pela Biscoito Fino em seus cinco anos de existência que, de uma maneira ou de outra, remetem ao atual panorama musical do bairro" 23 .

Estudos sobre a economia da cultura (PRESTES FILHO, 2002 e LESSA, 2002) reconhecem a "vocação histórica" do carioca para promover megaeventos. A Lapa e todo o agito econômico/cultural que promove não fica de fora dessa idealização. Investimentos privados nos setores de gastronomia, antiguidades, arte e entretenimento vêm crescendo, assim como o número de visitantes, notadamente a juventude da zona sul e os turistas ${ }^{24}$.

Sérgio Lessa (2002, p.151) diz que

Esta é uma cidade com vocação para o espetáculo dos grandes espaços. Até
porque, na minha hipótese básica, o que caracteriza ser carioca é considerar o
espaço público uma extensão do espaço privado. O carioca está na rua como se
estivesse em casa. Na minha opinião, é isso que define o carioca. A
disponibilidade de cenários naturais - praias, espelhos d'água, montanhas - criou
uma cultura do espaço aberto: a calçada, a praça, a rua.

Apesar do crescimento econômico estar circunscrito prioritariamente à exploração comercial em ambientes privados como as casas de shows, são esses os ingredientes - a imagem do carioca, o cenário lapiano como um reduto da boemia, a música - que promovem a economia da região atraindo visitantes de toda a parte, além, é claro, dos esforços governamentais como a implantação de projetos como a Quadra da Lapa e o Distrito Cultural da Lapa, por exemplo. Este é o cenário onde vamos encontrar atualmente um campo de trabalho para o músico que vem crescendo, conforme vão prosperando as casas de shows e os empresários que exploram esse setor. 


\section{trabalhonecessário}

issn: $1808-799 \mathrm{X}$

ano 7 - número 8 - 2009

De forma fenomênica, Lefê Almeida festeja e analisa o quadro que se encontra hoje na Lapa.

As noitadas musicais começavam a revelar novos e grandes talentos da nossa música popular. O público lotava o antiquário da Lavradio 100, o Semente e aquele pedaço da rua Joaquim Silva. Era um pessoal, na sua maioria jovens, ávido por escutar os clássicos do samba, saber da nossa história e usufruir da paz e alegria carioca, que o bom samba sabe dar. As estatísticas apontam para um público de 40.000 pessoas por mês entre cariocas e turistas. É extremamente gratificante ver que aquela verdadeira guerrilha cultural que vivemos nestas últimas três décadas não foi em vão. É gostoso saber que aquela música que não toca no rádio é ouvida hoje por milhares de pessoas que gostam dela e querem mais. É muito bom ver a quantidade de empregos gerados para músicos, artistas, produtores e pessoas ligadas à nossa cultura, além de outros segmentos que envolvem a mão-de-obra dos setores de turismo, alimentos, bebidas e entretenimento em geral ${ }^{25}$.

É desse mesmo ponto de vista que a mídia vem caracterizando a prosperidade econômica do local. Em reportagem da Revista Carta Capital (2007, n456, p.10) pode-se ler em destaque: "a nova onda de investimentos na Lapa reafirma a vocação que fez do tradicional bairro o símbolo do humor, da cultura, da diversidade e da boemia carioca". Apesar dos ingressos nas mais tradicionais casas de shows serem incompatíveis com o salário médio do cidadão brasileiro, a democratização desse espaço é afirmada pelos empresários da região, como o produtor musical Perfeito Fortuna que declara: "aqui dá certo porque não é de ninguém. Não é da zona sul, não é da zona norte, nem do rico nem do pobre" (Revista Carta Capital, 2007, n456, p.10).

O crescimento econômico é evidente não só pela proliferação das casas de shows e por sua ampliação, como é o exemplo da casa Rio Scenarium que pode atender cerca de 2 mil clientes em uma noite e que "inaugurou nova área anexa para cerca de 400 pessoas" (idem, p.11), mas também pela valorização dos imóveis. Segundo a citada matéria da revista Carta Capital "em 2001, um sobrado de 200 metros na Rua do Lavradio valia 60 mil reais. Hoje está na faixa dos 500 mil" (idem).

Apesar da "aura romântica" que pode envolver o trabalho de um músico, ainda mais em um cenário como o da Lapa, estão presentes nesses processos de trabalho todas as características e contradições das relações de trabalho que vêm se estabelecendo no capitalismo tardio. A exploração da força de 


\section{trabalhonecessário}

issn: $1808-799 X$

ano 7 - número 8 - 2009

trabalho se dá através de mecanismos criados pelos empregadores que, ao possuírem os meios de produção, detêm o controle da produção, da determinação do preço pago pela força de trabalho e da forma de pagamento, entre outros. São fixados limites sobre a quantia paga (em geral na forma de cachê ou de porcentagem sobre o ingresso ou couvert artístico), porém, não há limites para o lucro. Nesses ambientes de trabalho as relações informais predominam e mesmo sendo a música ao vivo a mola mestra que impulsiona a agitação das casas de shows, o músico é freqüentemente sujeito a condições cada vez mais precarizadas de trabalho.

Com o estudo de caso realizado na Lapa se buscou revelar que por trás dos jargões que pregam a democratização do acesso à cultura e o apoio à diversidade cultural temos, na realidade, um processo de transformação de manifestações culturais em mercadoria. A cultura transformada em mercadoria torna o trabalho do músico um trabalho produtivo ao capital, capaz de gerar lucro ao capitalista.

Processos de trabalho: especificidades da atividade profissional do músico no contexto das casas de shows da Lapa

O tipo de estabelecimento que aqui estamos nos referindo como casa de shows, segundo Franceschi (2002, p. 157), surgiu no Brasil na segunda metade do século XIX, e era chamado de café cantante. Nesses ambientes eram servidas comidas e bebidas e havia, "com maior ou menor aparato, um pequeno palco onde se podiam ouvir canções italianas e cançonetas francesas que faziam grande sucesso e, até mesmo, modinhas brasileiras" (idem). O autor indica o Alcazar Lyrique da antiga Rua da Vala (atual Rua Uruguaiana, Rio de Janeiro), como o primeiro estabelecimento desse tipo surgido no Rio de Janeiro (idem).

Gomes (1985), diz que por volta de 1930 o mercado para o músico nos bares foi estimulado através de uma intervenção do Governo Federal, que fixou 


\section{trabalhonecessário}

issn: $1808-799 \mathrm{X}$

ano 7 - número 8 - 2009

o preço do cafezinho em cem réis por xícara, mas que permitia às casas que

oferecessem música ao vivo cobrar o dobro do preço. "Muitos bares tinham conjuntos musicais, e o próprio Nice teve por muito tempo um conjunto integrado só por mulheres. E até ser fechado, o Nice possuía o nicho onde esse conjunto e outros tocaram" (p.22).

$\mathrm{Na}$ atualidade, o número de casas destinadas à música ao vivo na Lapa vem crescendo semana após semana. A Revista VejaRio, de 2 de agosto de 2006, publicou um mapa com 19 da casas mais "badaladas" da região, 14 delas oferecendo música ao vivo como atrativo principal.

O trabalho do músico nas casas de show da Lapa consiste, grosso modo, em preparar um repertório condizente com as expectativas de seu contratante, em geral a música popular brasileira dançante, com dia e hora marcada realizar sua apresentação. Mesmo simplificando dessa maneira, podemos indicar que o processo de trabalho do músico passaria ao menos por três etapas: preparação de repertório, passagem de som (o momento em que músicos e técnico de som ajustam os equipamentos de sonorização à formação instrumental e/ou vocal do grupo) e apresentação musical. Isso significa que o momento da apresentação de um grupo encobre um extenso processo de trabalho, que inclui várias etapas. Com efeito, cada etapa desse processo é desmembrada pela Classificação Brasileira de Ocupações (CBO) em diversas atividades e competências.

$\mathrm{Na}$ primeira etapa, onde é preparado o repertório, estão embutidas variadas funções. Mesmo que os músicos envolvidos no processo de trabalho não sejam os compositores das músicas a serem apresentadas há a necessidade, por exemplo, de que exerçam a função de arranjadores. Quando arranjadores, por exemplo, os músicos teriam como função, conforme a CBO: transcrever músicas, orquestrar a obra musical, adaptar obras musicais, definir a formação instrumental e/ou vocal do arranjo, redefinir a forma musical, redefinir melodia da composição musical, redefinir ritmo da composição musical, redefinir harmonia da composição musical, elaborar harmonização 


\section{trabalhonecessário}

issn: $1808-799 \mathrm{X}$

ano 7 - número 8 - 2009

vocal para coral (quando é o caso), registrar arranjo por meio de grafia musical

e registrar arranjo por meios eletrônicos (analógicos e/ou digitais).

A importância dessa etapa do trabalho - preparação do repertório - não poderia deixar de ser ressaltada, uma vez que é esse o atrativo usado pelas casas de shows para atrair sua clientela. Com freqüência os músicos têm de adaptar seu repertório e arranjos às diretrizes das casas que, da mesma forma que apresenta o seu cardápio com os petiscos e bebidas também apresenta ao público consumidor o seu cardápio musical. Em circular endereçada aos músicos atuantes no Rio Scenarium se lê:

Aniversários: é muito comum a comemoração de aniversários na casa como em outras do gênero. Fica estabelecido que 1 vez por noite deverá ser tocado o Parabéns pra Você, uma versão "meio gaiata bem humorada" pode ser uma boa saída para esta obrigação social.

Repertório: a casa prima pela boa qualidade das bandas e os repertórios devem priorizar sempre as obras de Noel, Cartola, Nelson Cavaquinho, Paulinho da Viola, Pixinguinha, Jacob do Bandolim, Waldir Azevedo, Luiz Gonzaga, Chico Buarque, entre outros de igual reconhecimento; a boa música é marca registrada da casa e os músicos são responsáveis pela manutenção desta marca; pagodes e funks ou similares não devem ser tocados mesmo quando pedidos por clientes.

Nesse sentido, o ex-diretor musical da casa Rio Scenarium Henrique Cazes diz que "tem uma definição de linha no Rio Scenarium que é a necessidade de se fazer alguma coisa ligada a um tipo de samba mais clássico. Uma coisa que não tivesse cara de pagode"26. Partindo desse princípio o diretor musical da casa seleciona os grupos através de gravações que Ihes são enviadas. Em alguns casos os grupos são formados em função dessa proposta, e em outras ocasiões alguns grupos são dirigidos a tocar o repertório definido pelo diretor musical.

Agora mesmo semana passada, o grupo Sanhaço, pessoal novinho, eles mandaram um disco pra mim todo com músicas do Jorge Aragão, etc. Eu falei: o grupo de vocês é legal, mas com esse repertório eu só posso colocar vocês no Mangue $^{27}$. Aí eles fizeram um repertório todo bacana de Noel, Nelson Cavaquinho, deram uma caprichada e fizeram muito bem. Então tem esse aspecto de dar uma cara, uma certa unidade. Não resvalar nessa cara mais brega, ficar uma coisa chique, música brasileira de qualidade. Porque quando você faz isso você agrada em média muito mais a qualquer tipo de público ${ }^{28}$.

Segundo Cazes, a escolha de grupos musicais e o direcionamento do repertório pela direção musical seria um diferencial oferecido aos clientes do 


\section{trabalhonecessário}

issn: $1808-799 \mathrm{X}$

ano 7 - número 8 - 2009

Rio Scenarium. A seleção dos grupos é realizada pelo diretor musical e "depois

que se toca lá pela primeira vez tem uma comissão que avalia: os sócios, o gerente, a moça que faz a parte de comunicação e marketing" ${ }^{29}$.

A última etapa do processo de trabalho, a execução musical, prevê uma etapa intermediária chamada de "passagem de som". A CBO inclui esta etapa na lista de exigências para que se cumpra a execução musical. As exigências são:

- Atentar para as condições exigidas para a execução (som, luz, acústica, local).

- Atentar para as condições do instrumento/voz.

- Realizar passagem de som.

- Preparar-se esteticamente para o espetáculo.

- Concentrar-se para a apresentação.

- Preparar-se física e mentalmente para a apresentação.

- Afinar instrumentos.

- Observar a platéia para adequar o roteiro musical.

- Manter sintonia com os membros do conjunto musical.

- Manter sintonia com as características do evento.

- Interpretar a obra musical em função do estilo e texto.

- Cantar representando.

- Tocar representando.

- Utilizar tecnologias para execução musical.

Apesar as casas exigirem do músico a realização da passagem de som (na citada circular aos músicos enviada pela casa Rio Scenarium se lê: "é imprescindível fazer a passagem do som com todos os integrantes da banda no horário combinado"), as casas de shows da Lapa, para efeito de remuneração, somente é contabilizada como trabalho a ser pago a função exercida pelos músicos na etapa de execução musical, ou seja, as horas gastas na apresentação musical. As horas disponibilizadas pelos músicos na 


\section{trabalhonecessário}

issn: $1808-799 X$

ano 7 - número 8 - 2009

realização da chamada "passagem de som", apesar de prevista como trabalho a ser pago segundo a Lei $n^{\circ} 3857$, lei que regulamenta o trabalho do músico, não são contabilizadas para efeito de remuneração. O músico é remunerado apenas por empregar sua força de trabalho no ato da apresentação musical, dando de graça ao capitalista todas as outras etapas do processo de trabalho, como, por exemplo, a preparação do repertório e a passagem de som. O modo de produção capitalista, que tem como uma de suas características a absorção de trabalho não pago, se utiliza de um processo histórico que fetichiza o trabalho artístico de forma a circunscrever e delimitar o trabalho musical apenas ao momento da performance.

Assim, a jornada de trabalho passa a contar a partir do momento que a apresentação do grupo começa, e o horário da apresentação é pré-estipulado pela casa, consistindo de sets de $1 \mathrm{~h}$ a $1 \mathrm{~h} 30$ de duração em média. Segundo a pesquisa empreendida, por noite pode-se trabalhar de dois a quatro sets, dependendo da movimentação da casa e de acordo com o interesse do empregador.

O trabalho nas casas de shows da Lapa pode ser de apenas um dia, um final de semana, uma semana inteira ou esporádico. No período deste estudo, apenas a casa Rio Scenarium se preocupou em não permitir que músicos trabalhassem por mais de 10 dias consecutivos a fim de não configurar o vínculo empregatício. Conforme a citada Lei $\mathrm{n}^{\circ} 3857$, mais de 10 dias de trabalho consecutivos configuram vínculo empregatício. Desta forma, os músicos que atuam no Rio Scenarium, depois de algumas apresentações (geralmente não mais que quatro dias consecutivos) entram numa espécie de "quarentena", só voltando a atuar na casa após esse período de quarenta dias, apesar de, como indicaremos adiante, não haver fiscalização nesse sentido.

A despeito da quantia paga, vale notar que em ambas as situações (legalizadas ou não) e mesmo onde se estabelece o vínculo empregatício haverá sempre a exploração da força de trabalho. Isso porque, como se pôde verificar, o empregador sempre irá procurar extrair o máximo de mais valia do trabalhador, ou seja, obter um "sobreproduto" através de um "sobretrabalho" 30. 


\section{trabalhonecessário}

issn: $1808-799 \mathrm{X}$

ano 7 - número 8 - 2009

Dito de outra forma, o montante pago será sempre menor do que o trabalho empreendido pelo trabalhador. Como em qualquer situação onde o trabalhador dispõe apenas de sua força de trabalho não dispondo dos meios de produção que nesse caso é a própria casa de shows e todo o seu aparato - os músicos acabam se sujeitando a trabalhar nessas condições.

Como forma de ocultar a manipulação do preço da força de trabalho do músico e, por conseqüência, a exploração desse trabalhador, a maioria das casas observadas em nosso trabalho empírico utiliza o que eles entendem como uma "parceria" entre empresários e músicos, através da divisão do "lucro" obtido com a cobrança do couvert artístico. Nesse caso, quanto maior é o público pagante maior seria o preço pago pelo trabalho dos músicos. Por outro lado, se não houver público não há remuneração. Em geral, as casas que utilizam esse sistema de pagamento por couvert artístico não têm um grande fluxo de público e, apesar de oferecer como produto principal a música ao vivo, condicionam o preço a ser pago por essa força de trabalho a quantidade de público pagante. O que ocorre é que independente de haver ou não público pagante ao menos as duas primeiras etapas do processo de trabalho são cumpridas (elaboração de repertório e passagem de som), porém não pagas.

Além disso, com a cobrança do couvert e o pagamento através de porcentagens atrelado ao número de público pagante a possibilidade de margem de lucro do empregador é sem limites. Essa situação de exploração se torna evidente através dos dados contidos em documentos que descrevem a quantia paga por serviços realizados em duas apresentações numa mesma casa de shows. Os documentos demonstram que o total pago ao artista nesse sistema de pagamento por couvert pode até inverter a relação público versus quantia paga, ou seja, que maior número de público não implica em maior remuneração pelo trabalho do músico.

Como demonstram tais documentos, em show realizado dia 21 de setembro de 2007, a apresentação de um grupo para 102 pessoas gerou um pagamento aos músicos superior ao show realizado dia 28 de setembro, onde a apresentação foi feita para 110 pessoas. Através de descontos e convites o 


\section{trabalhonecessário}

issn: $1808-799 X$

ano 7 - número 8 - 2009

empregador pode manipular o preço do ingresso ou até mesmo não efetuar sua cobrança quando de sua conveniência. De qualquer forma, o público estaria consumindo outros produtos oferecidos como comidas e bebidas. Como a quantidade de sobretrabalho não pode ser medida pelo tempo de trabalho, uma vez que sendo a apresentação realizada para uma ou mil pessoas os músicos fariam o mesmo tempo de performance, essa situação fica camuflada e naturalizada tornando-se habitual.

O pagamento por couvert artístico não é a forma legal de contratação de músicos, apesar de ser a mais freqüente. Segundo a presidente do SindMusi Déborah Cheyne "não se pode cobrar pela lei couvert artístico. Pode cobrar entrada, ingresso. O pagamento aos músicos sem a nota contratual é ilícito". De todas as casas pesquisadas só uma, o Rio Scenarium, paga através de nota contratual. Veremos adiante como isso também foi de sua conveniência.

A porcentagem paga aos músicos através do couvert artístico é também variável de acordo com os critérios dos contratantes. Nas casas observadas, as porcentagens variaram de $40 \%$ a $70 \%$ do preço cobrado ao público a título de couvert artístico. Essa variação é aparentemente aleatória e não se faz distinção alguma em relação à quantidade de músicos envolvidos no processo de trabalho. A divisão interna da remuneração, em geral, não fica a cargo do empregador, mas do próprio grupo. Quando há um intermediário entre o grupo e a casa de shows, figura essa denominada frequentemente como produtor musical, a soma recebida é também repartida com ele.

Das casas de show observadas, apenas duas pagam uma quantia fixa aos grupos que ali se apresentam: o Rio Scenarium e o Teatro Odisséia. Não seria uma coincidência que essas casas que trabalham com um preço fixo têm uma alta circulação de público pagante, ao contrário das que trabalham com couvert. No caso do preço fixo, a diferença entre o que é cobrado pelo ingresso ao público e o que é pago aos músicos fica como lucro para a casa, podendo chegar a diferenças exorbitantes, como no caso que veremos a seguir.

Em suma, temos uma situação que corresponde às expectativas capitalistas de acúmulo de capital, onde a forma de pagamento e o preço do 


\section{trabalhonecessário}

issn: $1808-799 X$

ano 7 - número 8 - 2009

trabalho do músico são determinados pelo contratante, assim como o que será trabalho pago e o que será trabalho não pago. Se o pagamento por couvert é conveniente ao empregador quando a freqüência do público é incerta, por outro lado se torna extremamente inconveniente quando a casa atrai grande número de público pagante, o que consequentemente aumentaria a remuneração do músico. Isso porque para o capital o preço do trabalho do músico tem um limite, mas o lucro não.

\section{A mercadoria do espetáculo: um bom "negócio"}

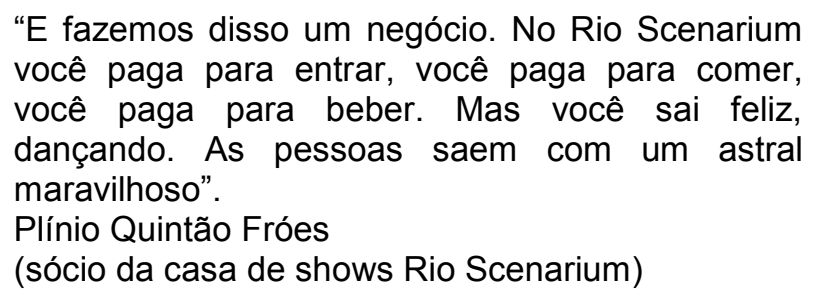

Para compreendermos melhor como vêm se dando os processos e as relações de trabalho do músico nas casas de shows da Lapa, área que vivencia atualmente um momento economicamente favorável ao desenvolvimento de atividades comerciais através das apresentações musicais ao vivo, foi escolhida uma das mais prósperas e consagradas casas shows da região como um dos focos desta pesquisa: o Rio Scenarium, casa situada na Rua do Lavradio.

Evidências dessa prosperidade podem ser observadas através de matérias divulgadas pela imprensa. Com efeito, em outubro de 2005, o Rio Scenarium foi eleito pela Revista Veja Rio como a "melhor casa com música ao vivo" da cidade ${ }^{31}$ e hoje essa casa configura na lista dos "10 melhores bares do mundo", segundo a seleção do jornal londrino "The Guardian", assumindo a nona posição nesse ranking ${ }^{32}$.

A casa de shows tem como sede os números 18 e 20 da Rua do Lavradio além de um anexo nos números 15 e 17 da Rua Visconde de Ouro 


\section{trabalhonecessário}

issn: $1808-799 \mathrm{X}$

ano 7 - número 8 - 2009

Branco. O ex-diretor musical da casa, Henrique Cazes nos conta que o Rio

Scenarium existe desde 1999 em dois imóveis geminados que foram adquiridos através de leilão público ${ }^{33}$.

Inicialmente funcionando como um antiquário, em 2001, foi inaugurado o "Rio Scenarium - Pavilhão da Cultura", onde se passou a oferecer uma programação regular de música, espetáculos de teatro e exposições, além do serviço de bar e restaurante. Posteriormente, o teatro foi desativado pela incompatibilidade com o som muito alto da casa de shows que se tornou o investimento prioritário, conforme nos contou Henrique Cazes.

Os donos do Rio Scenarium tinham um antiquário que ainda existe como empresa. Eles têm uma loja lá que aluga material, carruagem, aluga pra televisão, cinema e tal. Então aquele prédio foi reformado aos poucos. De repente pintou aquele sobrado na Visconde do Ouro Branco que pertence ao Instituto Rio Previdência e eles alugaram a casa e recuperaram o imóvel. Então, criou-se um anexo, uma parte administrativa. Começou assim: dois donos de antiquário resolvem abrir uma coisa que tem bar, que tem música, eles começam a se meter em um monte de assunto que eles não conhecem, então resolveram profissionalizar todos os aspectos: cozinha, cardápio, segurança, todos os aspectos da coisa ${ }^{34}$.

Segundo um dos sócios do Rio Scenarium, Plínio Quintão Fróes, sua entrada para o ramo de compra e venda de antiguidades foi um acaso: "nunca foi do meu campo de interesse" ${ }^{35}$. Junto com uns amigos comprou um box de venda de antiguidades na Rua do Lavradio, porém, nenhum dos sócios tinham experiência nessa área.

Segundo o empresário, apesar da degradação em que se encontrava a Rua do Lavradio, o público que freqüentava o local "era um público qualificado. [...] Um público formador de opinião, é um público que gosta de arte, que gosta de cultura, é um público que valoriza uma peça de arte, que valoriza o móvel bom, que valoriza a qualidade do móvel”36. Por esse motivo diz que havia uma grande preocupação com o estado de conservação da rua ${ }^{37}$. Com o intuito de oferecer melhores condições ao público freqüentador dos antiquários da Rua do Lavradio foi criada uma feira de antiguidades, em outubro de 1996. Plínio Quintão Fróes comenta que a criação da feira "aconteceu em um momento 


\section{trabalhonecessário}

issn: $1808-799 X$

ano 7 - número 8 - 2009

muito importante, aconteceu no local certo, na hora certa e no momento certo e com as pessoas certas também nos apoiando nos postos chaves"38.

Provavelmente o empresário está se referindo aos projetos promovidos pela prefeitura do Rio de Janeiro com o objetivo de revitalização da Região Centro. Não é por acaso que o sócio da mais "badalada" casa de shows da Lapa, que é ainda dono de diversos outros imóveis na região, faça parte da comissão do Plano Estratégico da prefeitura do Rio de Janeiro para a Região Centro $^{39}$.

Apesar de a Região Centro ser uma das localidades da cidade do Rio de Janeiro com a maior quantidade de equipamentos culturais ${ }^{40}$, os dados levantados pelo Plano Estratégico identificaram na região a falta de opções de lazer e acesso à cultura, incluindo a baixa oferta de eventos musicais ${ }^{41}$. Esses dados foram levantados entre 2001 e 2002, na fase de diagnóstico da pesquisa, através do "Plano Estratégico da Cidade do Rio de Janeiro: Pesquisa de Percepção".

O Plano teve por objetivo "identificar as potencialidades da área, a partir de seus aspectos positivos, vocações e manifestações culturais próprias”. Foram apontadas como potencialidades de desenvolvimento na região as manifestações culturais como as escolas e rodas de samba, os artistas de rua, os eventos de artes plásticas, música e teatro e as feiras de artesanato, de antiguidades e regionais como potencialidades da região. $O$ turismo histórico/cultural e o lazer cultural figuram entre os pontos vocacionais desta localidade ${ }^{42}$.

Desta forma, entre os objetivos centrais do Plano Estratégico está a meta de tornar a Região Centro o "centro de referência histórico-cultural do país". Para atingir essa meta a estratégia proposta é a de: (1) estabelecer bases institucionais para a criação do Centro de Referência Histórico-Cultural da Cidade e (2) definir política de recuperação, revitalização e utilização dos espaços públicos e prédios históricos ${ }^{43}$.

Assim, o interesse na preservação dos casarões e das ruas e a criação de formas de se atrair um público cada vez maior para a região, tanto do setor 


\section{trabalhonecessário}

issn: $1808-799 \mathrm{X}$

ano 7 - número 8 - 2009

privado como do público estão em sintonia. O projeto do Plano Estratégico

indica que "esse patrimônio insubstituível deve ser preservado, cultivado e quando for o caso - restaurado, não só pela importância cultural e histórica, mas considerando-se também a atração turística que exerce" ${ }^{44}$, ou seja, a capacidade de movimentação econômica.

Através de Orçamento Participativo ${ }^{45}$, do qual faz parte da comissão o sócio da casa de shows Rio Scenarium Plínio Quintão Fróes, o Plano Estratégico para a Região Centro prevê a

Implantação de corredor iluminado formado pela Cinelândia, Lapa, Rua do Lavradio, Praça Tiradentes, Largo da Carioca e Praça XV, Praça da República, Rua Frei Caneca, Beco da Sardinha, Estácio, Rio Comprido, Catumbi, Cidade Nova, Santa Teresa e Paquetá, com a criação de circuitos culturais voltados para a região, integrando as favelas à rede de equipamentos históricos culturais e de lazer ${ }^{46}$.

Não seria por acaso que, ao lado de bairros e praças públicas, a Rua do Lavradio se destaca entre os locais beneficiados pelo projeto. Sobre os primórdios da Feira de Antiguidades da Rua do Lavradio, o empresário Plínio Quintão Fróes diz que o sub-prefeito do centro, na época, Augusto Ivan de Freitas Pinheiro "contribuiu muito para transformar e dinamizar o comércio no centro da cidade".

Acho que o Augusto Ivan, com o seu grupo de trabalho, colaboradores, como a Olga Bronstein, que era administradora regional e outras pessoas, eles tiveram um papel muito grande de apoiar, de ouvir a comunidade dos comerciantes. Mas também, ouviu a comunidade de uma forma geral. Então é difícil falar do processo da Lavradio sem falar sobre o Augusto Ivan, que ele foi um dos criadores do corredor cultural da prefeitura. Então já tinha todo um movimento de revitalização que vinha no trabalho dele ${ }^{47}$.

Segundo o empresário, em seu primeiro mês de funcionamento, outubro de 1996, a Feira do Rio Antigo, como foi chamada, recebeu seis mil visitantes. "O Rio de Janeiro inteiro baixou lá. Gente famosa, gente bonita, muitos artistas, escritores, poetas, jornalistas. Foi assim um grande sucesso. A feira trouxe a Rua do Lavradio para mídia, trouxe o público para a Rua do Lavradio" ${ }^{48}$.

Para a promoção da feira, além das antiguidades, o público encontrava "os restaurantes na calçada vendendo chopp, salgadinhos", além de músicos que se apresentava no local. Foi um primeiro momento desta fase onde a 


\section{trabalhonecessário}

issn: $1808-799 \mathrm{X}$

ano 7 - número 8 - 2009

receita que unia um ambiente que apresentava um diferencial (as antiguidades)

com música e serviço de bar e restaurante parecia dar certo. Segundo Plínio, "tudo muito focado no nosso negócio que era antigüidade. Na nossa rua, que é onde o nosso negócio estava" (grifos nossos) ${ }^{49}$.

A necessidade de melhoria das condições das calçadas, da iluminação, do sistema de esgoto, enfim, da condição geral da Rua do Lavradio e de seu entorno foi o que motivou, segundo o depoimento de Plínio Fróes, as reformas promovidas pela prefeitura.

E com o sucesso da feira trouxe no seu bojo o projeto de reforma da Rua do Lavradio, projeto de recuperação da Rua do Lavradio promovido pela prefeitura no primeiro governo do César Maia ainda. O projeto foi apresentado através do Augusto Ivan, que sempre ouviu a comunidade. Levava para Rio Urbe, trazia para discutir com a gente. Então o projeto da Lavradio é vencedor, ele deu certo porque ele foi discutido conosco desde o início. A proposta que foi nossa, a prefeitura respondeu ${ }^{50}$.

O negócio dos antiquários para Plínio Quintão Fróes e seus sócios foram se expandindo com a aquisição de novas lojas na Rua do Lavradio. O empresário nos conta como se deu a expansão de seu negócio e das casas de show que foram prosperando nos arredores do Lavradio. O Rio Scenarium

Se transformou em um espaço cultural. Com música, com dança, com teatro. E isso faz parte de um processo. Com a feira da Rua do Lavradio, a feira dinamizou a região, revitalizando a região com a abertura de novos espaços. O primeiro deles foi o Empório 100, na Rua Lavradio, número 100, é um espaço com música, com choro, com samba dentro do antiquário da Lu. Depois o Carioca da Gema, com Tiago e com Lefê que já faziam a parte da música e do restaurante do Empório. Aí eles saíram e montaram o Carioca da Gema. A Lu continuou com outro grupo, mais o Alberto. E aí veio o Semente na Lapa. [...] E aí veio a Casa da Mãe Joana, veio o Sacrilégio, ao lado do Carioca da Gema. O Centro Cultural Carioca, na Rua do Teatro. O Espaço Constituição. Então a região foi ganhando força, a subprefeitura sempre atuante. [...] E esses espaços culturais sempre trazendo para o centro do Rio, um público muito especial. Um público qualificado ${ }^{51}$.

Sobre a profissionalização das rodas de samba e choro da Lapa a instrumentista Luciana Oliveira diz que o Empório 100 (no número 100 da Rua do Lavradio) era a única casa na época (por volta de 1998) que tinha música ao vivo na Lapa de forma mais organizada ${ }^{52}$.

O Empório 100 começou com o grupo Dobrando a Esquina fazendo uma roda nas sextas-feiras, sem som, era tudo acústico e era uma roda que todo mundo entrava. Depois foi incrementando e começaram a não deixar todo mundo 


\section{trabalhonecessário}

issn: $1808-799 \mathrm{X}$

ano 7 - número 8 - 2009

participar da roda, começaram a botar som. O Lefê foi quem inventou essa história de botar samba em um antiquário. Era cobrado do público um preço baratinho. Quando começou a lotar eles começaram a botar música em outros dias. Eu peguei essa época primeiro assistindo e depois tocando com os Chorões da Lapa $^{53}$.

A instrumentista comenta que era frequentemente chamada pelo empresário Plínio Quintão Fróes para tocar na Feira do Lavradio: "Uma vez foi o Vídeoshow e ele me chamou. Dizia que não tinha muito dinheiro pra pagar, mas que seria legal e tudo bem. A gente ia e depois aparecia no Vídeoshow" 54.

Amparada por promessas de sucesso, a exploração da força de trabalho do músico é hábito, e os músicos são de fácil persuasão. Quando não há a garantia de remuneração há a crença que depois de certo tempo um público seria formado e os músicos seriam, assim, gratificados. Isso é o que Juliana Coli (2006) identificou como as poderosas armas - como a 'amizade', o 'sacrifício' e o 'interesse' - "dos empresários e do próprio capital, no sentido de obter o máximo de usufruto da força de trabalho do músico" (COLI, 2006, p.101). O depoimento de Luciana Oliveira ilustra essa situação:

Depois que ele [Plínio Quintão Fróes] criou o Rio Scenarium começou a chamar uns grupos pra tocar. O primeiro grupo que tocou lá foi o Pau da Braúna. Mais ou menos nos primeiros seis meses que tocaram lá não ganharam praticamente nada. O Garrafieira também. Eles pagavam por couvert e os músicos tocavam em dias fixos 55 .

Hoje, a casa de shows Rio Scenarium funciona de terça a quinta a partir das $18 \mathrm{~h} 30 \mathrm{~min}$ e as sextas e sábados a partir das $19 \mathrm{~h}$, oferecendo sempre dois shows ${ }^{56}$. Durante o dia, a casa fica aberta funcionando não como antiquário, mas como loja especializada para locações de cinema, teatro, televisão. Segundo o sócio Plínio o negócio é bastante lucrativo.

Por quê? Aquelas peças ali são pecas específicas para cenários. Nós temos quartos art déco, art noveau, a sala império, em diversos estilos com objetos, com tapete, com luminária, anos 50 . Então, tipos de cenários completos para locação. Então daqui a um ano, dois anos a produtora quer voltar aqui para um ambiente igual, para continuar um filme, por exemplo, que foi interrompido. Essas peças vão estar aqui ainda. $E$ nos antiquários não acontecia isso. Você alugava, como logo vendia, você perdia aquele acervo. Aquilo eu não vendo de jeito nenhum, é uma verdadeira galinha dos ovos de ouro. Porque a gente vende aos pedacinhos e a peça continua sempre da gente. É o melhor negócio que tem ${ }^{57}$. 


\section{trabalhonecessário}

issn: $1808-799 \mathrm{X}$

ano 7 - número 8 - 2009

De terça a quinta, os shows acontecem às $19 \mathrm{~h}$ e $22 \mathrm{~h}$, respectivamente, com ingressos a 15 reais, e nas sextas e sábados às $19 \mathrm{~h} 30 \mathrm{~min}$ e $22 \mathrm{~h} 30 \mathrm{~min}$ com ingressos a 25 reais.

Hoje, o Rio Scenarium é uma das casas da região da Lapa que conta com o maior número de público pagante por noite. O ex-diretor musical Henrique Cazes informa que eles não investem em divulgação, pois não poderiam atender um maior número de pessoas. Ele diz: "divulgar pra fazer o quê? Aonde vai colocar aquelas pessoas? Já ta cheio!" 58 .

Porém, não foi sempre assim. Conforme comentamos, no início desse processo de revitalização da Lapa o público ainda era incipiente, e foi através de estratégias como a criação da Feira de Antiguidades da Rua do Lavradio que empresários como Plínio Quintão Fróes atingiram seu objetivo. Nesse período inicial, conforme comentou Luciana Oliveira, o pagamento aos músicos era feito por couvert artístico. Segundo a musicista, a movimentação do público quando começou a aumentar (e consequentemente a quantia paga aos músicos já que era na base da porcentagem) aconteceu um incidente que "obrigou" a casa a regularizar a situação com os músicos passando a pagar preço fixo por nota contratual ${ }^{59}$.

Segundo a versão do ex-diretor musical Henrique Cazes,

O Ministério do Trabalho cresceu o olho em cima daquela situação ali que começou a movimentar uma quantidade de dinheiro muito grande e multou a casa porque os músicos estavam tocando lá de semana em semana ou de 15 em 15 dias criando vínculo empregatício. A casa pagou a multa e o músico passou a ficar de "quarentena" pra poder atuar ali de novo. Isso é um problema que se configurou $^{60}$.

O problema que se configurou, na versão dos músicos, foi que os empresários entenderam que o montante pago aos músicos, nessa forma de combinação (por couvert), ficou muito elevado, e resolveram mudar o esquema passando a fixar uma quantia independente do número de público pagante. Além disso, os músicos que tinham um posto fixo de trabalho passaram a ter que alternar suas apresentações com outros grupos para não configurar o vínculo empregatício. É a chamada "quarentena". Segundo a musicista Luciana 


\section{trabalhonecessário}

issn: $1808-799 \mathrm{X}$

ano 7 - número 8 - 2009

Oliveira os músicos que atuavam na época nessa casa tentaram uma espécie de boicote à casa de shows que não funcionou ${ }^{61}$.

Ora, essa foi apenas uma estratégia empresarial de geração de lucro. Pagando por couvert o trabalho do músico em nada onera o contratante uma vez que não há a obrigação de pagamento caso não haja público pagante. Uma vez conquistada pela casa certa fama e com uma maior e crescente freqüência de público, se torna mais vantajoso o pagamento por cachê fixo. Todo o excedente fica como lucro para a casa. A casa de shows ao expandir sua capacidade de acolher o público aumenta até onde for fisicamente possível sua margem de lucro.

Sobre a regularização da contratação dos músicos na casa Rio Scenarium Alan Magalhães, diretor administrativo do SindMusi, comenta:

Por conta da legislação que cria o vínculo empregatício se o músico começar a trabalhar direto, eles começaram a fazer um rodízio de músicos e isso desagradou aos músicos que estavam lá ganhando dinheiro. Os músicos ficaram indignados e saíram do Rio Scenarium, o que foi pior pra eles porque eles poderiam estar no revezamento ${ }^{62}$.

Luciana Oliveira comenta a fragilidade das negociações entre empresários e músicos. Ela diz que a negociação é complicada porque a possibilidade de ter seu trabalho apresentado em uma casa reconhecida como o Rio Scenarium representaria para o músico algum tipo de benefício além do econômico:

Lá é um lugar onde se pode mostrar o trabalho artístico porque tem público pra ver. E a coisa ficou assim porque mal ou bem era bom trabalhar sabendo que iria receber aquele dinheiro fixo e as pessoas continuaram a tocar. Tem fila de músicos querendo tocar lá. A casa é luxuosa, dá status ${ }^{63}$.

Após o episódio relatado entre o Rio Scenarium e o Ministério do Trabalho, os músicos passaram a receber por nota contratual. Quando questionados sobre o porquê da única casa da Lapa que estaria sendo "obrigada" a seguir as normas conferidas ao trabalho do músico pela Portaria n³347, que estabelece a nota contratual, Alan Magalhães, diretor administrativo do SindMusi, e Déborah Cheyne, presidente dessa instituição, dizem que não há uma fiscalização efetiva. 


\section{trabalhonecessário}

issn: $1808-799 X$

ano 7 - número 8 - 2009

Existe uma carência de fiscais. A lei determina que haja um grupo especial de fiscalização para músicos, artistas e técnicos em espetáculos. Acontece que por conta dessa carência esse mesmo grupo fiscaliza outras categorias, especialmente a construção civil, que tem questões como periculosidade, insalubridade. Acaba que os músicos ficam em segundo plano, há a fiscalização, só que não atinge um patamar significativo ${ }^{64}$.

Déborah Cheyne diz que a fiscalização seria também uma atribuição da Ordem dos Músicos do Brasil, conforme vimos também previsto na Lei n³857, mas que "a OMB fiscaliza o músico e não necessariamente a relação de trabalho". Assim, os músicos se sentem aviltados em ter seu acesso ao trabalho submetido ao pagamento de uma taxa anual que não lhe traz benefício algum ${ }^{65}$.

Os representantes do SindMusi dizem que para que uma casa seja autuada deve haver denúncia. Segundo eles, esse foi o caso do Rio Scenarium.

Fomos procurados pelos músicos. Houve uma reclamação dos músicos em relação à informalidade então nós propusemos um acordo coletivo. Fizemos um acordo com o Rio Scenarium que por sua vez, quando começou a vigorar o acordo, eles deram um jeito de se beneficiar. $\mathrm{O}$ acordo era dar aos músicos $\mathrm{O}$ valor integral do couvert artístico ou uma nota contratual com cachê fixo. Eles começaram a fazer dessa maneira, a dar o couvert artístico integral, mas o movimento começou a aumentar e os músicos começaram a ganhar muito. Ao ver o movimento crescer passou a pagar por nota, pois assim teria que dar todo couvert para os músicos. Eles viram que poderiam pagar um cachê razoável e ainda ter lucro. Não há nada de ilegal nisso desde que eles cumpram o que determina a lei em relação aos impostos. ${ }^{66}$.

O Rio Scenarium, assim como as demais casas de shows da Lapa, baseado em seus próprios critérios e interesses, determina: a duração da jornada de trabalho, o que é trabalho pago e o que é trabalho não pago, o preço a ser pago pelo trabalho, a forma de calcular esse preço, a forma de pagamento, além de estabelecer o que deve constar no cardápio musical oferecido aos clientes. As formas de se extrair mais valia são muitas, e mesmo quando "regularizadas" as casas de show encontram formas de aumentar sua margem de lucro e extrair, legalmente, a mais valia do trabalho do músico. Assim, para as casas de shows o trabalho do músico representa um alto 


\title{
trabalhonecessário
}

issn: $1808-799 X$

ano 7 - número 8 - 2009

potencial como valor de troca, configurando-se em trabalho produtivo ao capital.

\section{Relações de trabalho: o trabalho produtivo do músico nas casas de shows da Lapa.}

\author{
“O processo capitalista de produção não é \\ meramente produção de mercadorias. É um \\ processo que absorve trabalho não pago, que \\ transforma os meios de produção em meios para \\ sugar trabalho não pago". \\ Karl Marx
}

Quando consumido como valor de uso o trabalho do músico é improdutivo. Conforme Marx (1975)

Quando se compra o trabalho para o consumir como valor de uso, como serviço, não para colocar como factor vivo no lugar do valor do capital variável e o incorporar no processo capitalista de produção, o trabalho não é produtivo e o trabalhador assalariado não é trabalhador produtivo. O seu trabalho é consumido por causa do seu valor de uso e não como trabalho que gera valores de troca; é consumido improdutivamente (MARX, 1975, p.95).

Porém o sentido do trabalho na economia capitalista aponta para a subsistência do trabalhador e para o acúmulo de capital através da extração da mais valia. O trabalhador, através do produto de seu trabalho, produz mais valia para o capitalista. Assim, seu trabalho é caracterizado como trabalho produtivo.

É produtivo aquele trabalho que valoriza diretamente o capital, o que produz maisvalia, ou seja, que se realiza - sem equivalente para o operário, para o executante - numa mais-valia, representada por um sobreproduto; isto é, que se realiza num incremento excedentário para o monopolista dos meios de trabalho, para o capitalista (MARX, 1975, p.93).

Apesar de na aparência as casas de shows da Lapa não serem identificadas como produtora de mercadorias, mas sim como prestadora de serviços (serviço de bar, música ao vivo, etc.), em sua essência são produtoras de uma engrenagem que agrega em seu conjunto o comércio de comidas e bebidas, o ambiente (que no caso do Rio Scenarium está revestido de antiguidades que dariam a casa certa identidade) e a música ao vivo. Pela 


\section{trabalhonecessário}

issn: $1808-799 \mathrm{X}$

ano 7 - número 8 - 2009

aparência, o trabalho dos garçons e dos músicos, por exemplo, seriam

díspares quando na verdade, em sua essência, colaboram para a consecução de determinada produção.

No contexto das casas de shows da Lapa, se considerado improdutivo, poderíamos entender que o trabalho do músico é vendido diretamente ao público consumidor, podendo ser o empresário considerado como um "parceiro" ao "ceder" suas instalações ao músico para que possa realizar seu trabalho. Ao contrário disso entendemos que o músico, em casas de shows como o Rio Scenarium, é trabalhador subordinado ao capital que the explora sobretrabalho, ou seja, mais valia.

Nesse sentido poderíamos dizer que o ingresso pago pelo público ao entrar na casa seria o símbolo de todo um processo produtivo, considerando seus meios de produção (o imóvel e suas instalações, os equipamentos de sonorização, a matéria-prima para a cozinha e o serviço de bar, entre outros) e a compra da força de trabalho (como a dos cozinheiros, garçons, faxineiros, seguranças e músicos). O trabalho do músico "trata-se, portanto, de trabalho que serve diretamente ao capital como instrumento da sua auto-valorização, como meio para a produção de mais-valia" (MARX, 1975, p.93). Importante notar que apesar do músico possuir alguns meios de produção, como os instrumentos musicais, não tem controle sobre os processos de produção. $O$ músico não estaria vendendo ao capitalista um produto musical, mas sim sua força de trabalho através de formas específicas de assalariamento. Em tais formas estão embutidos artifícios encontrados pelo capital para encobrir a real exploração do trabalho do músico.

Conforme Marx (1975), entendemos o músico no contexto das casas de shows da Lapa como um trabalhador coletivo quando "a sua atividade combinada realiza-se materialmente e de maneira direta num produto total" ( $p$. 94). Na medida em que seu processo de trabalho age como um instrumento de valorização do capital, de criação de mais valia, "o processo de trabalho subsumi-se no capital (é o processo do próprio capital), e o capitalista entra nele como dirigente, guia" (idem, p.73). 


\section{trabalhonecessário}

issn: $1808-799 \mathrm{X}$

ano 7 - número 8 - 2009

Citando como exemplo o caso do Rio Scenarium, a exploração da força

de trabalho do músico pôde se intensificar quando as instalações da casa foram ampliadas acolhendo maior número de público pagante, valendo-se também da tecnologia que permite ampliar a propagação da música ao vivo, o que permite ao capitalista um "excedente de produção".

Marx fala sobre o excedente da produção como aquele "produto que nada custa ao capitalista" (1975, p.93), no caso citado representado pelo excedente de ingressos vendidos. Assim, quanto maior for a capacidade de receber maior número de público pagante maior será o excedente, ou seja, o lucro, já que o preço do trabalho do músico na casa Rio Scenarium, conforme já comentado, é fixo.

Para que seu trabalho fosse improdutivo o preço do ingresso teria de ser pago diretamente ao músico, aí sim o trabalho seria consumido pelo público como um serviço e seria, portanto, improdutivo ao capital. Mas, no contexto do trabalho como o realizado no Rio Scenarium, ao gerar mais valia o trabalho do músico torna-se produtivo. $\mathrm{O}$ empresário é o intermediário entre público e músicos, é aquele que possui o capital para investir na produção do espetáculo, para criar as condições de sua produção e de seu consumo. Seu interesse no trabalho do músico se estabelece na medida em que esse trabalho pode representar valor de troca. O consumidor paga ao intermediário na forma de compra de ingresso, onde está embutido o dinheiro investido e onde todo o excedente será lucro para o intermediário. Quanto maior for a capacidade da casa em absorver público pagante maior será o lucro, uma vez que os gastos na produção do espetáculo não varia, apenas a margem de lucro aumenta. Essa é uma das formas encontradas pelo capitalista de extração de mais valia.

Marx (1975) reitera:

Todos os meios de trabalho produzidos, independentemente do serviço que prestem como valores de uso no processo de produção, funcionam agora simultaneamente como elementos do processo de valorização. Quando não se transformam em dinheiro real, convertem-se em moeda imaginária, são tratados como valores de troca e o elemento de valor que, duma maneira ou doutra, acrescentam ao produto é calculado com exatidão (MARX, 1975, pp.125-126). 


\section{trabalhonecessário}

issn: $1808-799 \mathrm{X}$

ano 7 - número 8 - 2009

Como exemplo, citamos o depoimento do ex-diretor musical do Rio

Scenarium Henrique Cazes quando indicou que em recente final de semana a casa bateu recorde de público com 1902 pagantes em um único dia. Isso quer dizer que 1902 ingressos foram vendidos a 20 reais, o que gerou a soma de 38 mil e 40 reais $^{67}$. Segundo as informações de Cazes, foi pago aos músicos um cachê fixo de 3.600 reais. Assim, a casa ficou com a diferença, ou seja, 34.440 reais. O que nos interessa demonstrar com esse cálculo é que, hoje, com a ampliação das instalações do Rio Scenarium, a casa pode abrigar mais 400 pessoas aumentando seu lucro, posto que o trabalho dos músicos não se alterou. É a expressão do trabalho do músico sendo produtivo ao capital.

Entender o trabalho do músico como produtivo se torna importante na medida em que ajuda a esclarecer a relação estabelecida entre contratante e contratado. Pensando nessa direção podemos esclarecer que não há parcerias ou divisão de lucros, como aconteceria supostamente no caso do pagamento por couvert, segundo a opinião dos empresários. Do mesmo modo, entender as etapas que compõem os processos de trabalho do músico revela o trabalho não pago oculto na forma fenomênica das apresentações ao vivo.

Como resultado do presente estudo foi possível constatar que em todas as suas formas, sendo elas legalizadas ou não, a exploração da força de trabalho do músico nas casas de show da Lapa se perpetua amparada por um regime econômico que permite ao capitalista adequar tais relações de trabalho da forma que lhe assegure e amplie a sua margem de lucro. Ao considerar apenas o valor de uso do trabalho do músico, se encoberta a complexidade do seu processo de trabalho e, consequentemente, fragilizam-se as suas relações de trabalho. Pudemos, assim, evidenciar a produção musical como um setor imerso nos processos gerais da produção capitalista, cujas determinações históricas vão moldando e adequando seus processos e suas relações de trabalho às necessidades capitalistas de produção e geração de lucro. 


\section{trabalhonecessário}

issn: $1808-799 X$

ano 7 - número 8 - 2009

REFERÊNCIAS BIBLIOGRÁFICAS

ANDRADE, Moacyr. Lapa: alegres trópicos. Rio de Janeiro: Relume Dumará: Prefeitura, 1998.

COLI, Juliana. Vissi D'Arte por amor a uma profissão: um estudo sobre a profissão do cantor no teatro lírico. São Paulo: Annablume, 2006.

FISCHER, Ernst. A necessidade da arte. São Paulo: Círculo do Livro, s.d.

FRANCESCHI, Humberto M. A Casa Edison e seu tempo. Rio de janeiro: Sarapuí, 2002.

GOMES, Bruno Ferreira. Wilson Batista e sua época. Rio de Janeiro: FUNARTE, 1985.

LESSA, Carlos. A economia do lazer e o nascimento da indústria cultural de massa. In: Economia da cultura: a força da indústria cultural no Rio de janeiro. Rio de Janeiro: Faperj e Coppe/UFRJ, 2002, pp.141-152.

MARX, Karl. Capítulo inédito D'o Capital: resultado do processo de produção imediato. Porto: Publicações Escorpião, 1975.

PRESTES FILHO, Luiz Carlos. Cultura e economia: a articulação necessária entre indústria e poder público. In: Economia da cultura: a força da indústria cultural no Rio de janeiro. Rio de Janeiro: Faperj e Coppe/UFRJ, 2002, pp.13-21.

ENTREVISTAS CITADAS

(em ordem alfabética)

- ALAN MAGALHÃES (Diretor Administrativo do SindMusi).

Entrevista concedida dia 18 de outubro de 2006.

- DÉBORAH CHEYNE (Presidente do SindMusi).

Entrevista concedida dia 18 de outubro de 2006.

- HENRIQUE CAZES (músico e produtor musical).

Entrevista concedida dia 18 de julho de 2006.

- LUCIANA OLIVEIRA (músico).

Entrevista concedida dia 25 de julho de 2007.

\footnotetext{
${ }^{1}$ Doutora em Educação. Bolsista CNPq/UFF Pós-Doutorado Júnior.

2 Segundo dados contidos na matéria "Lapa quente" da revista Veja Rio (ano 15, n³0, julho/agosto de 2006).

${ }^{3}$ O Centro é um dos 14 bairros da Região Centro. Os outros bairros dessa Região são: Benfica, Caju, Catumbi, Cidade Nova, Estácio, Gamboa, Mangueira, Paquetá, Rio Comprido, Santa Teresa, Santo Cristo, São Cristóvão e Saúde (www.rio.rj.gov.br/planoestrategico, consultada em 3 de agosto de 2007).

${ }^{4}$ www.rio.rj.gov.br/planoestrategico, consultada em 3 de agosto de 2007.

${ }^{5} \mathrm{O}$ morro do Castelo foi derrubado em 1922.

${ }^{6}$ www.marcillio.com/rio/encelapa.html, consultada em 7 de agosto de 2007.
} 


\section{trabalhonecessário}

issn: $1808-799 X$

ano 7 - número 8 - 2009

${ }^{7}$ www.rio.rj.gov.br/planoestrategico, consultada em 3 de agosto de 2007.

8 http://portalliteral.terra.com.br/Literal/calandra, consultada em 7 de agosto de 2007.

${ }^{9}$ www.rio.rj.gov.br/planoestrategico, consultada em 3 de agosto de 2007.

10 "Foi num cabaré na Lapa que eu conheci você, fumando cigarro, entornando champanhe no seu soirée. Dançamos um samba, trocamos um tango por uma palestra. Só saímos de lá meia hora depois de descer a orquestra. Em frente à porta um bom carro nos esperava mas você se despediu e foi pra casa a pé. No outro dia lá nos Arcos eu andava à procura de um cabaré. Eu não sei bem se chorei no momento em que lia a carta que eu recebi (não lembro de quem). Você nela me dizia que quem é da boemia usa e abusa da diplomacia mas não gosta de ninguém".

11 "Foi na Lapa que eu nasci foi na Lapa que eu aprendi a ler. Foi na Lapa que eu cresci e na Lapa eu quero morrer. A Lapa também tem a sua igreja pra que todo mundo veja onde eu fui batizado. A Lapa onde já não há conflito fica no Quinto Distrito aonde eu fui criado. Um samba, um sorriso de mulher bate-papo de café eis aí a Lapa”.

12 www.rio.rj.gov.br/planoestrategico, consultada em 3 de agosto de 2007.

13 O Circo Voador é um dos ícones da juventude nos anos 1980. Entre outras atividades culturais, foi um local onde havia apresentações das bandas de rock nacionais que começavam a ganhar notoriedade na cidade e, posteriormente, em todo o país. Groppo (1996, p.24, apud Vicente, 2002, p.120) destaca: "debaixo da lona azul, o Circo Voador ajudou a promover o primeiro 'Verão do Rock', além de abrigar grupos teatrais e oficinas, apresentações e cursos de dança, acrobacia, capoeira e música. Nestes quatro meses em que funcionou no Arpoador, o Circo Voador revelou dois grupos muito importantes nesta primeira fase do rock nacional, a Blitz e o barão Vermelho. Obrigado a mudar de local, o Circo foi para o bairro da Lapa... (onde) promovia todo sábado o evento Rock Voador, com apresentação de bandas de rock cariocas... o projeto era patrocinado pela rádio Fluminense FM".

14 Vicente (2002, p.118 em diante) faz uma análise do que o rock brasileiro representou para a indústria fonográfica naquele momento, o que foi sinalizado pelos shows realizados no Circo Voador. Ele diz que "o rock dos anos 80 foi o primeiro cenário fora do âmbito da MPB a permitir a formação de um grupo de artistas de carreira duradoura e vendas mais ou menos constantes. Trouxe, também, todas as sinalizações da adequação do mercado fonográfico brasileiro ao padrão predominante nos países centrais: direcionamento da indústria a um público jovem, LP como formato predominante e vendas baseadas em repertório nacional" (idem, p.119).

15 A Fundição Progresso é um espaço cultural administrado por uma ONG, que deteve a concessão do estado. O espaço ocupado era onde funcionava uma fundição de fogões e cofres (www.fundicao.org, consultada em 11 de outubro de 2006).

16 O projeto intitulado "Distrito Cultural da Lapa" foi assinado pelo então governador Garotinho em junho de 2000, e teve sua inauguração, com apoio da Petrobrás, em agosto de 2005.

(www2.petrobras.com.br/CulturaEsporte/portugues/cultura/PatrimonioEdificado/CulturalL apa.htm, consultada em 25 de ago. de 2006).

17 Este Decreto, em seu artigo $1^{\circ}$, determina que "Fica instituído o Projeto 'DISTRITO CULTURAL DA LAPA' consistente na destinação de imóveis próprios estaduais não afetados ao uso comum do povo ou ao uso especial e alocados ao Poder Executivo Estadual ou pertencentes a entidades vinculadas, para atividades culturais e outras correlatas". Segundo Bruno Dorigatti, em artigo disponível em www.arteepolitica.com.br/download/ap9.pdf, consultada em 16 de agosto de 2006, o Distrito Cultural da Lapa visa, além da recuperação arquitetônica, o "desenvolvimento sócioeconômico sustentado na produção e no turismo cultural. Além da restauração, estão previstos a implementação de serviços essenciais, como segurança, sinalização, iluminação, 


\section{trabalhonecessário}

issn: $1808-799 X$

ano 7 - número 8 - 2009

estacionamento e requalificação da mão-de-obra pobre e excluída da Lapa através de cursos de arte, teatro, música, dança, línguas, história do bairro, turismo, hotelaria, para ser empregada nas atividades que o distrito propõe".

18 Apesar dessa delimitação a área denominada Lapa não tem fronteiras muito bem definidas. Nos diversos mapas da região encontrados pela internet e em documentos, além da fala de muitos dos músicos entrevistados para esta pesquisa, também é considerada, muitas vezes, como parte integrante da área cultural da região da Lapa a Praça Tiradentes, onde se situam o Teatro João Caetano, o Teatro Carlos Gomes, a Gafieira Estudantina (hoje chamada de Nova Estudantina) e o Centro Cultural Carioca (este último situado na Rua do Teatro).

${ }^{19}$ Depoimento encontrado em http://oglobo.globo.com/rio/ancelmo/marceunalapa, consultada em 17 de setembro de 2007.

${ }^{20}$ Entrevista concedida em 18 de julho de 2006.

${ }^{21}$ Depoimento encontrado em http://oglobo.globo.com/rio/ancelmo/marceunalapa, consultada em 17 de setembro de 2007.

22 Os serviços e mercadorias com a marca "Lapa" vão ter valor agregado à seus produtos, na medida em que essa marca acrescenta um valor de uso estético à esses mercadorias e serviços. Nesse sentido Haug (1997) diz que "o valor de uso estético prometido pela mercadoria torna-se então instrumento para se obter dinheiro. Desse modo, o seu interesse contrário estimula, na perspectiva do valor de troca, o emepenho em se tornar uma aparência de valor de uso, que exatamente por isso assume formas bastante exageradas, uma vez que, da perspectiva do valor de troca, o valor de uso não é essencial" (p.27). Mais adiante o autor continua: "A função da valorização sempre à procura de uma resposta para a questão da realização encontra expressão justamente na aparência exagerada do valor de uso, impelindo o valor de troca contido na mercadoria ao encontro do dinheiro. Ansiosa pelo dinheiro, a mercadoria é criada na produção capitalista à imagem da ansiedade do público consumidor. Essa imagem será divulgada mais tarde pela propaganda, separada da mercadoria" (p.35).

${ }^{23}$ www.biscoitofino.com.br, consultada em 28 de março de 2007.

${ }^{24}$ www.armazemdedados.rio.rj.gov.br/arquivo, consultada em 16 de jun. de 2006.

${ }^{25}$ Depoimento encontrado em http://oglobo.globo.com/rio/ancelmo/marceunalapa, consultada em 17 de setembro de 2007.

26 Em entrevista concedida dia 18 de julho de 2006.

${ }^{27}$ A Cachaçaria Mangue Seco pertence aos mesmos donos do Rio Scenarium e é destinada a um público de menor poder aquisitivo que o público da segunda casa..

${ }^{28}$ Entrevista concedida em 18 de julho de 2006.

29 idem.

30 Sobre isso ver "Salário, preço e lucro" (MARX , 1978).

31 http://veja.abril.com.br/vejarj/300403/badalacao.html, consultada em 3 de agosto de 2007.

$32 \mathrm{http} / / / \mathrm{www}$.guardian.co.uk/travel/2006/nov/28/bars, consultada em 3 de agosto de 2007.

33 Em entrevista concedida dia 18 de julho de 2006.

34 Entrevista concedida em 18 de julho de 2006.

35 Depoimento encontrado em www.museudapessoa.net/MuseuVirtual, consultada em 3 de agosto de 2007.

36 Idem.

37 O ex-diretor musical do Rio Scenarium Henrique Cazes aponta também para essa preocupação com o entorno do local que abriga a casa: "O Rio Scenarium está ainda restaurando uma fachada [de outro imóvel na mesma rua] porque é do interesse que aquilo não caia em cima das pessoas que estão na fila. É uma casa de cômodos que pertence a um português que está em Portugal e que não quer saber. Existe esse aspecto também, você precisa fazer pelo entorno, pra criar um lugar mais bonito e mais seguro". 
38 Encontrado em www.museudapessoa.net/MuseuVirtual, consultada em 3 de agosto de 2007.

${ }^{39}$ Conforme o documento encontrado em www.rio.rj.gov.br/planoestrategico, consultada em 3 de agosto de 2007.

40 Entre museus, bibliotecas, escolas e sociedades musicais, espaços e centros culturais, galerias de arte, teatros e salas de espetáculos, cinemas e bens tombados (www.armazemdedados.rio.rj.gov.br, consultada em 9 de agosto de 2007).

${ }^{41}$ www.rio.rj.gov.br/planoestrategico, consultada em 3 de agosto de 2007.

42 Idem.

${ }^{43}$ Idem.

${ }^{44}$ Idem.

45 O Orçamento Participativo (OP) seria "um processo dinâmico que se adequa periodicamente às necessidades locais, buscando sempre um formato facilitador, ampliador e aprimorador do debate entre o Governo Municipal e a população". No Brasil, foi inicialmente implementado em Porto Alegre. "Por ser um importante instrumento de participação popular, o OP é referência para o mundo. Conforme a ONU, a experiência é uma das 40 melhores práticas de gestão pública urbana no mundo. O Banco Mundial reconhece o processo de participação popular de Porto Alegre como um exemplo bemsucedido de ação comum entre Governo e sociedade civil" (www2.portoalegre.rs.gov.br/op/default.php?p_secao=1, consultada em 9 de agosto de 2007). Em sentido oposto, Augusto de Franco em artigo publicado on-line diz que "o 'Orçamento Participativo' restringiu a participação cidadã apenas à disputa em torno de prioridades governamentais que atendessem aos interesses particulares de um grupo, setor ou localidade. Desperdiçando o imenso potencial das comunidades e dos indivíduos, porquanto dirigindo-os ou canalizando-os somente para exigir do governo essa ou aquela ação pontual - desconectada de um sonho de futuro, de um diagnóstico e de um planejamento participativos - o chamado 'Orçamento Participativo', além de gerar dispersão de esforços, transformou as instâncias de participação em campos adversariais de confronto, tendo como resultado experiências de democracia de baixa intensidade e com alto grau de antagonismo. A concepção de poder subsumida nessas experiências de democracia de baixa intensidade, mesmo sendo rotulada como participativa, era uma concepção do poder para o confronto, do poder para a disputa, do poder para fazer prevalecer os interesses de um grupo, setor ou localidade, sobre os interesses de outros grupos, setores ou localidades" (www.eagora.org.br/conteudo.php?cont=artigos\&id=2425_0_3_0_M7, consultada em 9 de agosto de 2007).

46 www.rio.rj.gov.br/planoestrategico, consultada em 3 de agosto de 2007.

${ }_{47}$ Depoimento encontrado em www.museudapessoa.net/MuseuVirtual, consultada em 3 de agosto de 2007.

48 Idem.

49 Idem.

50 Idem.

51 Idem.

52 Em entrevista concedida à autora em 25 de julho de 2007.

${ }^{53}$ Idem.

${ }^{54}$ Idem.

${ }^{55}$ Em entrevista concedida à autora em 25 de julho de 2007.

56 Recentemente o Rio Scenarium passou a abrir também às segundas-feiras, porém com uma programação musical diferenciada dos demais dias.

57 Depoimento encontrado em www.museudapessoa.net/MuseuVirtual, consultada em 3 de agosto de 2007. 


\section{trabalhonecessário}

issn: $1808-799 X$

ano 7 - número 8 - 2009

58 Henrique Cazes indica com espanto o sucesso do Rio Scenarium apesar de haver pouca ou nenhuma divulgação da casa. Contrariando essa afirmação já mencionamos algumas matérias publicadas na imprensa enaltecendo a casa, e o sócio do Rio Scenarium, Plínio Quintão Fróes, atribui à mídia, em seu referido depoimento, o sucesso da Feira do Lavradio e, consequentemente, do Rio Scenarium.

59 Em entrevista concedida à autora em 25 de julho de 2007.

60 Entrevista concedida à autora em 18 de julho de 2006.

61 Em entrevista concedida em 25 de julho de 2007.

62 Em entrevista concedida à autora em 18 de outubro de 2006.

63 Em entrevista concedida à autora em 25 de julho de 2007.

64 Em entrevista concedida à autora em 18 de outubro de 2006.

65 Idem.

66 Idem.

67 Esse era o preço do ingresso quando foi realizada a entrevista com o então diretor musical do Rio Scenarium Henrique Cazes. 